\section{SOI: 1.1 TAS DOI: $10.15863 /$ TAS International Scientific Journal Theoretical \& Applied Science}

Kamol Khoshim ugli Usmonov Senior researcher, Lieutenant colonel, Tashkent Higher Military-Technical Academy Ministry of Internal Affairs of the Republic of Uzbekistan Tashkent, Uzbekistan naumenko06@mail.ru

p-ISSN: 2308-4944 (print) e-ISSN: 2409-0085 (online)

naumenkolo mail.ru

Year: $2016 \quad$ Issue: 4 Volume: 36

Published: $30.04 .2016 \quad \underline{\text { http://T-Science.org }}$

SECTION 30. Philosophy.

\title{
THE DEVELOPMENT OF MILITARY-PATRIOTIC EDUCATION IN UZBEKISTAN AS A SPIRITUAL AND MORAL FACTOR IN THE FORMATION OF HARMONIOUSLY DEVELOPED PERSON
}

\author{
Abstract: In this article some aspects of the formation and development of the military-patriotic education in \\ Uzbekistan are considered. \\ Key words: the military-patriotic education, patriotism, Armed Forces, young people, harmoniously developed \\ person, spirituality. \\ Language: English \\ Citation: Usmonov KK (2016) THE DEVELOPMENT OF MILITARY-PATRIOTIC EDUCATION IN \\ UZBEKISTAN AS A SPIRITUAL AND MORAL FACTOR IN THE FORMATION OF HARMONIOUSLY \\ DEVELOPED PERSON. ISJ Theoretical \& Applied Science, 04 (36): 83-85. \\ Soi: http://s-o-i.org/1.1/TAS-04-36-12 Doi: crossef http://dx.doi.org/10.15863/TAS.2016.04.36.12
}

Pursuing peaceful course in international relations the Republic of Uzbekistan at the same time assumes the functions of protection of life and dignity of its citizens realizes the inherent right of defense in accordance with the UN Charter, provides military power and defense capability of the state to the level of reasonable sufficiency. "In the surrounding us a troubled world - said Islam Karimov in his speech to the deputies of the Oliy Majlis - there are not only friends, but there are also those who would like to draw Uzbekistan in the sphere of its influence. They can use any methods available to them, including the military. For this we need to have a mobile, well-trained and equipped army, capable of defending our borders, our independence and sovereignty".

Preparing of young people for service in the Armed forces of the Republic of Uzbekistan is the task of national importance, in its decision an important role to play schools, lyceums, colleges, special educational institutions. In all secondary schools introduced as a compulsory subject of preconscription training of young men. Teachers of this subject, namely, pre-conscription training of young men and physical education prepare the Universities of the Republic of Uzbekistan.

The military-patriotic education is an integral part of youth education. The theory and practice of the military-patriotic education based on the Constitution of the Republic of Uzbekistan, ideas of the President of the Republic of Uzbekistan about patriotism and the protection of a sovereign, independent country, laws, decrees of the Oliy Majlis, decrees of the Ministry of Defense, the provisions of the military pedagogy and psychology, military science and others.

In Article 52 of the Constitution of the Republic of Uzbekistan noted, "Protection of the Republic of Uzbekistan is the duty of every citizen of the Republic of Uzbekistan". Based on this military doctrine, approved by the Oliy Majlis, determines the Main directions of preparation of economy, territory and population for defense. In particular it identifies that the military-patriotic education of the population is:

1. In the system of training of youth of premilitary age and conscripts for military service in schools and other educational institutions, organizations of the Republic of Uzbekistan.

2. The Armed Forces of the Republic of Uzbekistan with the passage of the personnel of the military service.

3. In schools, high schools, on military faculties and in military departments of civilian universities of the Republic of Uzbekistan. Forces.

4. In special forces, transmitted to the Armed

"Love to the Land, to the Motherland, noble feelings are eternal features of the national character, which has become the flesh and blood of our people. To preserve, protect and develop these valuable human qualities, to raise our children worthy sons 
and daughters of a free and democratic Uzbekistan all of these would become the main directions of our work in the field of spirituality" - said Islam Karimov.

The main principles of the military-patriotic education are:

1. The principle of scientific objectivity.

2. The principle of concrete historical approach.

3. The main tasks and directions of the militarypatriotic education of students.

The main tasks of the military-patriotic education are to develop a sense of pride in our independent, sovereign, walking on its way Motherland, the love of the Armed Forces, loyalty and militant labour traditions, respect for military labour: shaping constant willingness skillfully and bravely with arms in their hands to defend our freedom and independence to perform their civic duty.

The aim of the military-patriotic education is the formation of attitudes, beliefs, world views, ensuring readiness to defend their Fatherland, to give it all the power, and if it will need even life, moralcombat qualities of future warriors.

The directions of the military-patriotic education:

1. The formation of young people moralpolitical and psychological qualities of defenders of the Motherland is the heart of the military-patriotic education. The formation of young people the military-patriotic education includes two elements:

- moral and political;

- psychological.

Moral and political:

1. To know the history of Uzbekistan.

2. To forme a sense of pride in our independent, sovereign, walking on his way Motherland.

3. To form the loyalty to the military and labor traditions of the Uzbek people.

4. To form a constant willingness skillfully and bravely with arms in their hands, to defend our freedom and independence, fulfilling their civic duty.

5. To form a sense of loyalty to their native places, and for this we need to know our territory, province, the village that grows to produce on their land.

6. Especially students should know about labor and combat exploits of the Uzbek people during the Second World War.

7. To form the political, moral attitudes and beliefs of students in the spirit of love and devotion to their Homeland.

8. We should always remember the words of our President - "Love for the land, the Motherland, the grateful feelings are eternal features of the national character, which has become the flesh and blood of our people. To preserve, protect and develop these valuable human qualities, to bring these valuable human qualities, to raise our children worthy sons and daughters of a free and democratic Uzbekistan - all these would be the main focus of our work in the field of spirituality".

The second direction of the military-patriotic education of military-technical direction. In the course students acquire qualities such as military knowledge, combat skills, discipline, self-discipline, strict compliance with the oath and statute.

In our country paid the great attention to the training of military personnel (staff officers). Since 1918 functioning "The Tashkent Higher combined arms school", in Chirchik - "Tank school", etc.

The great progress in the training of military personnel was the organization of the military departments, the military preparing for secondary schools, at the leading Universities of the Republic of Uzbekistan.

In our country the military-patriotic education is carried out also by specialized organizations. One of them is "Vatanparvar" ("Patriot"). Organization for promotion of defense of Uzbekistan "Vatanparvar" is a non-profit organisation, the legal form of a public Association, created on the basis of joint activity to protect common interests united the citizens by the military-media, sports-technical and militarypatriotic orientation and achieve the statutory goals of the Organization.

The Charter of the organization was reregistered on May 21, 2013 the Ministry of Justice of the Republic of Uzbekistan.

The purpose of the organization to promote the defense of Uzbekistan "Vatanparvar" is to contribute to strengthening the defensive might of the Armed Forces of the Republic of Uzbekistan, training youth and citizens to work and defend the Homeland, promote through the system of their organization to the public authorities in promoting of ideas of defending the homeland among the youth and the citizens, education of youth in patriotic spirit.

To achieve the assumed objectives, the Organization performs the following tasks:

- preparation of technical military specialists for the Armed Forces, training of specialists of mass professions for the national economy;

- development and promotion of technical and applied sports in the country;

- participation together with regional, state, public and non-profit organizations in the education of youth and citizens in the spirit of patriotism, and various military-patriotic events.

Organizational-mass work, military-Patriotic activity of the Organization on the basis of the organization's Charter, Constitution and laws of the Republic of Uzbekistan, decrees of the President of the Republic of Uzbekistan and government regulations. 


\begin{tabular}{l|lrl|l|ll} 
& ISRA (India) & $=\mathbf{1 . 3 4 4}$ & SIS (USA) & $=\mathbf{0 . 9 1 2}$ & ICV (Poland) & $=\mathbf{6 . 6 3 0}$ \\
Impact Factor: & ISI (Dubai, UAE) $=\mathbf{0 . 8 2 9}$ & PUHIL (Russia) $=\mathbf{0 . 2 3 4}$ & PIF (India) & $=\mathbf{1 . 9 4 0}$ \\
& GIF (Australia) & $\mathbf{0 . 5 6 4}$ & ESJI (KZ) & $=\mathbf{1 . 0 4 2}$ & IBI (India) & $\mathbf{= 4 . 2 6 0}$ \\
& JIF & $\mathbf{1 . 5 0 0}$ & SJIF (Morocco) & $=\mathbf{2 . 0 3 1}$ & & \\
\hline
\end{tabular}

\section{References:}

1. (2014) Konstituciya Respubliki Uzbekistan. Tashkent, Uzbekistan, 2014

2. (1997) Zakon RUz "Ob obrazovanii". 29 avgusta 1997.

3. (2016) Zakon RUz "O vseobshchej voinskoj obyazannosti i voennoj sluzhbe". gl. II, st. 12.

4. Karimov IA (2013) Uchitelyam i nastavnikam Uzbekistana // Na puti reshitel'nogo prodolzheniya dal'nejshego procvetaniya i modernizacii strany. Tom 21 /I.A.Karimov. T.: «Uzbekistan», 2013

5. Karimov IA (2007) Vystuplenie na torzhestvennoj ceremonii, posvyashchyonnoj 15-letiyu nezavisimosti Respubliki Uzbekistan // Liberalizaciya obshchestva, uglublenie reform, povyshenie duhovnosti i urovnya zhizni naroda - kriterij i cel' vsej nashej deyatel'nosti. T.15. - Tashkent: Uzbekistan, 2007. - pp.3-4.
6. Karimov IA (2002) Spravedlivost' - v prioritete zakona // Za bezopasnost' i mir nado borot'sya. T.10. - Tashkent: Uzbekistan, 2002. - pp.28.

7. Karimov IA (1996) Uzbekistan: svoj put' obnovleniya i progressa // Uzbekistan: nacional'naya nezavisimost', ehkonomika, politika, ideologiya. T.1. - Tashkent: Uzbekistan, 1996. - pp.44.

8. Karimov IA (2008) Yuksak ma"naviyat engilmas kuch. Toshkent, Uzbekiston.

9. (2000) Koncepciya voennogo obrazovaniya RUz. (Proekt).

10. (1997) Nacional'naya programma po podgotovke kadrov.

11. (1994) Prikaz MO RU N137 ot 20.07.94. "O vvedenii $\mathrm{v}$ dejstvie Polozheniya o vysshih voenno-obrazovatel'nyh uchrezhdeniyah Ministerstva oborony Respubliki Uzbekistan". 